\title{
IS JORDAN SAFE TO VISIT? THE IMPACT OF PERCEIVED RISK PERCEPTIONS ON THE TOURIST BEHAVIOURAL INTENTIONS
}

\author{
Ashraf Mohammad ALFANDI* \\ Irbid National University, Department of Tourism Management, Near Nuaima Bridge, 21110 Irbid, Jordan, e-mail address: aalzu3by@ yahoo.com
}

Citation: Alfandi A.M. (2020). IS JORDAN SAFE TO VISIT? THE IMPACT OF PERCEIVED RISK PERCEPTIONS ON THE TOURIST BEHAVIOURAL INTENTIONS. GeoJournal of Tourism and Geosites, 33(4spl), 1545-1550. https://doi.org/10.30892/gtg.334spl15-606

\begin{abstract}
The aim of this study was to investigate the influence of perceived risk dimensions on the tourists behavioural intention (BI). A questionnaire was prepared drawing from the scales in literature, and it was applied in a form of a self-administered questionnaire on European tourists who visited Jordan in 2018. To check the hypotheses on a data set of 339 completed questionnaires, multiple regression tests were applied. The findings identified that perceived financial risk (FR) and perceived performance risk (PR) had significant impact on tourists BI, however, perceived physical risk (PHR), perceived time risk (TR), and perceived socio-psychological risk (SPR) risk were not significant. The findings reflect only the perceived risks and BI of European tourists visiting Jordan. The focus should be placed on reducing implemented taxes on the touristic services and products in order to make Jordan more price competitive. This study establishes an empirical relationship between the risk dimensions and the BI of tourists; consequently, the findings have implications for the tourism industry, especially for key players in the Jordanian Tourism Board. It also serves as a reference to destinations with similar risk background.
\end{abstract}

Key words: precieved risk dimensions, behavioural intentions (BI), European tourists, Jordan.

* $\quad * \quad * \quad * \quad * \quad *$

\section{INTRODUCTION}

It is generally agreed that Tourism destination (TD) must be seen and perceived as a risk-free and safe place to visit. This will have a positive impact on the purchase, re-purchase, and on the tourists' intention to distinguish positive word-of-mouth (WOM) (El-Said and Aziz, 2019). This is definitely what managers for tourist destinations call as marketing tools. They are trying so hard to prove that their destination is safe. They are aware of the fact that tourism industry is a service-oriented industry and experience in its nature and susceptible to threats such as crime, socio-political instability, terrorist attack (Sönmez and Graefe, 1998b), disasters (Tasci and Gartner, 2007) and diseases (Rittichainuwat and Chakraborty, 2009). In the case of Jordan as TD, Jordan is a country surrounded by an abundance of conflicts and disputes, and after any disturbances perceived by the potential tourist as a risk factor, the tour operators and hotel business remain on edge and jittery as the tourists' inflow in the country will be declined. The works of literature support the fact that perception of risks is playing a critical role in the tourists' behaviour and decision making (Kozak et al., 2007; Sönmez and Graefe, 1998a). However, every destination has its unique attributes as well as perceived risk perceptions which impact the BI, and therefore, this relation between the perception of risks and tourist BI in the context of Jordan as tourism destination needs to be further investigated (Chew and Jahari, 2014). This was supported by Roehl and Fesenmaier (1992) who pioneered the research on tourists' risk perceptions. They found that perceptions of risks and travel behaviour are specific to the situation, proposing that travelers perceive risks differently toward different destinations and thus, the need to study destination-specific risk perceptions (Chew and Jahari, 2014). With little empirical literature on how potential tourists perceived Jordan as TD exists, and how such perceptions would affect their BI, the present study aims to explore the types and levels of risks of Jordan as TD and tourist's BI (i.e., repurchase intention and word-of-mouth intention).

1. The Jordanian Tourism Industry and the European market

In 2017, The World Travel and Tourism Council (WTTC) ranked Jordan as number 69 out of 185 countries worldwide in terms of the tourism industry contribute to the national GDP (7,632.8 million USD). As a TD, Jordan offers a wide range of cultural and natural tourist attractions, ranging from the virtually untouched scenery of the protected area of Wadi Rum to the ancient rose-red city Petra, and the Dead Sea's mineral shores (Al-Oun and Al-Homoud, 2008; Liu et al., 2016). Nevertheless, Jordan has been recently struggling with neighboring conflicts and is no stranger to disturbances. Specifically, this region has undergone many widespread conflicts over time such as the Arab Spring that started in 2010, the current civil war in Syria, the continuing conflict in Iraq, the emergence of the s o-called Islamic State of Iraq and Syria (ISIS) and the Palestinian-Israeli conflict. Naturally, the Western media would not leave all of these events without transmitting, and thus the region where Jordan is located has been harmfully affected and the tourist perception will be so negative, even though Jordan is still considered a safe country. A study by Ahmed and Kadir (2013), for example, indicated that information sources, particularly the mass media, harm the destination image especially after events such as political instability.

Jordan is seen as one of the countries indirectly affected by terrorist threats and has witnessed several decreases in the number of visitors and tourists (Farajat et al., 2017). Jordan's tourism industry considers the European tourism outbound market as one of the most important markets. Based on the statistics, in 2018, Jordan received about 3.5 million international tourists, about 700,000 of them were European tourists, and this number is growing rapidly (Jordanian Ministry of Tourism and Antiques, 2018). Besides, the Jordanian ministry of tourism and antiques (2018), highlighted the increase in the number of tourists coming from the Asia-Pacific region, followed by tourists from. Europe, however, this particular segment market prefers to travel to safe and secure destinations and avoid exposure to natural disasters, political instability and/or terrorist attacks. Increasingly, they rely on social media and review sites as the main sources of information when deciding to travel to a specific destination (Country Brand Index, 2018). As such, a good marketing campaign is the one that meets their needs and desires since this market offers a good opportunity to develop the tourism industry in many countries. To do that, we still need to know how risky they perceived Jordan as a tourism destination.

\footnotetext{
${ }^{*}$ Corresponding author
} 


\section{Risk Dimensions of TD}

An earlier work of Moutinho, (1987) classified the risk associated with the TD into four categories; health concern, crimes concern, terrorists attack concern, and the war and political instability concern. Later, Roehl and Fesenmaier (1992) categorized it into seven forms of risks like equipment, satisfaction, social, physical, financial, time, and psychological risks. Sönmez and Graefe (1998a) added three other factors to the work of Roehl and Fesenmaier (1992) that are health, political instability, and terrorism. On the other hand, Tsaur et al. (1997) grouped the risk perceptions related to the TD into two types of risk (physical and equipment risks). While the PHR is the possibility that an individual's health is at risk, injury and sickness, the equipment risk is the dangers arising from the malfunctioning of equipment, such as unsafe transportation (Tsaur et al., 1997). Other risk factors that were not considered by previous studies were added by Rittichainuwat and Chakraborty (2009) like lack of novelty, travel inconvenience, and deterioration of tourist attractions. A more recent study by Artuğer (2015) focused more on the risks of terrorism and political instability and how these two factors affect the traveler BI. It has been graded as PHR and psychological risks by Sohn et al. (2016). They argued that individual events (illness or injury), environmental conditions (warfare or weather) and social contact such as cross-cultural differences could be experienced by the person who conducts tourist activities. An important contribution to understanding the perception of risks associated with TD is the study of Perpiña et al. (2017), which examined the perceived risks in international tourism. They argued that the experience of tourism could be affected by multiple risk factors whether natural and/or man-made events such as natural disasters, contagious diseases, wars, and terrorist attacks. Liu et al. (2016) conducted an extensive study to try to answer the question of how risky it to travel to Jordan. Their research applied the framework for risk assessment (RPA) in connection with tourist destinations. The RPA theoretical framework originally provides a comprehensive interpretation of individual risk perception attitudes, indicating that the perception of individual risk attitude is characterized by perceived perceptions of danger and efficacy beliefs (Rimal and Real, 2003). Nevertheless, their analysis was limited to the level of terrorism risk, so they did not cover all forms of risks perceived by potential tourists that would deter them from visiting Jordan apart from the type of risk of terrorism.

After reviewing 62 destination image and risk perception papers from 1997 to 2014, Perpiña et al. (2017) included all possible risk factors that could be used in an instrument to test this concept and finally identified 50 risk attributes that could match any TD. From the 50 attributes, 5 risk perception factors associated with international travel were established by Perpiña et al. (2017): (1) PHR, (2) destination risks, (3) value-time risks, (4) personal concerns and (5) inconveniences. Another contribution was added by Hasan et al. (2017) who conducted a comprehensive literature review of the potential risks associated with tourism activities and categorized it into six dimensions; these are PHR, FR, PR, social risk, psychological risk, and security risk. Different studies have approached risk perceptions differently over the past two decades, resulting in a large number of different scales, typologies, and attributes. This leads to confusion about how to conceptualize and operationalize the perception of risk in tourism research, due to the lack of agreement on what factors to consider when assessing the perception of risk. Fuchs and Reichel (2006) identified the same six types of risk associated with TD that was recognized later by Hasan et al. (2017), however, due to the difficulties of the interviewed tourists to distinguish between the psychological and social risks, Fuchs and Reichel combined the psychological and social risks into a one risk factor (SPR). As a result, the current study used Fuchs and Reichel (2006) five dimensions of perceived risks which are; PHR, FR, TR, SPR, and PR. Mitchell, Davies, Moutinho and Vassos (1999) argued that risk dimensions vary depending on the type of tourism activities. For instance, backpackers may not encounter the same kind of risk factors as religious or health tourists experienced. Others claimed that potential tourists perceived risks could be changed from time to time and from destination to destination (Artuğer, 2015; Hasan et al., 2017). When tourists perceive the destination as an uncertain place to visit, this affects their minds and discourages them from traveling to the destination or sometimes to the region as a whole (Fuchs, 2013). It is therefore critical for TD managers to recognize what risks potential tourists perceive when they planning an international trip (Lehto et al., 2008).

\section{Tourist's BI}

The intention is usually a subjective judgment about how we will act in the future (Blackwell et al., 2001). It is the future action of referrals, price sensitivity, repurchase, and complaining behaviour (Zeithaml et al., 1996). On the other hand, an earlier study by Fishbein and Ajzen (1975) identified BI as the role of evaluative beliefs, normative beliefs, and situational factors that can be expected at the time of the holiday plan or commitment. Thiumsak and Ruangkanjanases (2016) argued in favour of measuring the tourist's BI by looking at their desirable to return as the most significant consequences suggesting that it is the main part of BI. Nevertheless, since tourism is a service-oriented business that is intangible in nature and tourists can't determine the service until buying it, the BI of the touris $t$ will vary accordingly (Lončarić et al., 2016; Litvin et al., 2008). We can't say that repurchase intention is the only predictor for BI.

This is because many potential tourists seeking novelty and therefore their intention to suggest the destination to others and to distinguish WOM represent good indicators for their BI (Phillips et al., 2013). Therefore, in the context of tourism industry, Barlas et al., (2010) clear the tourist BI as the planned future activity of the tourist reflected by the intention of returning and/or the desire to suggest the destination to others (Lončarić et al., 2016; Castro et al., 2007).

Previous studies find WOM to be an important source of information when making a purchase decision (Confente and Russo, 2015), an important marketing tool (Bao and Chang, 2014), vital when the service is complex (Zeithaml, 1988), and a critical source of information, especially when the service is at high perceived risk (Litvin et al., 2005). As such, the present study argued in favour of measure tourist BI by considering both factors which are; revisit intention and the willingness to recommend the destination.

\section{Perceived risk and the tourist BI}

The perception of risk was generally used to describe a concept of people's attitude and intuitive risk judgments (Cui et al., 2016). It was described by Stone and Gronhaug (1993) as a certain level of probability that can be attached to risk to determine the probable loss. The perceived risk could also be characterized as the probability that action might expose tourists to the danger that can influence travel decisions if the perceived danger is deemed to be beyond an acceptable level according (Reichel et al., 2007). Sönmez and Graefe (1998b) examined the perceived risk issue and found it to be a key factor in preventing travel to a risky destination. Roehl and Fesenmaier (1992) who pioneered the tourists' risk perception studies find that risk perceptions and travel behaviours tend to be specific to the situation, indicating that tourists interpret risks differently to different destinations and therefore there is a need to examine every destination-specific perceptions of risks.

Generally, the engagement of tourist activities usually occurs for several motivations such as health purposes, excitement, leisure, cultural, sports events and sometimes seeking novelty (Madden et al., 2016). The last thing the tourists want is to waste his precious holidays and to be in a dangerous destination; hence the perceived risk has become a pressing concern for tourists around the world. In addition to that, as mentioned earlier, the product of tourism is perceived riskier since it is susceptible to threats such as crime and socio-political instability, terrorists attack, diseases, and disasters (Sönmez and Graefe, 1998b; Rittichainuwat and Chakraborty, 2009; Tasci and Gartner, 2007). As such, potential tourists make their decision to travel to the destination based on their perceptions and not reality (Moisescu and 
Bertrea, 2013) even though some times the perception differs from reality (Roehl and Fesenmaier, 1992). This is particularly true since a safe destination or perceived safety is considered a pull factor as well as a very important destination attribute that initiates the desire for travel. Based on that, managers of TD are trying so hard to prove that their destination is a risk-free place to visit since perceived risk has been found to have a significant impact on the pre-visit decision by alerting rational decision-making about destination choices (Sönmez and Graefe, 1998a). Destinations marketers are aware that perceived risks of vacationing or travel to a specific destination have become specifically influential on tourists' decision-making behaviours given awareness of tragic events in foreign places. To this end, a destination must be viewed by prospective visitors as safe and protected from the danger posed by any unexpected incidents and that what referred to as perceived safety.

\section{RESEARCH HYPOTHESES}

Based on the theoretically accepted knowledge mentioned above, the current study estimates that perceived dimensions of risk associated with Jordan as a tourism destination influence the BI of tourists. The current study has therefore proposed the following hypotheses:

H.1: PHR affects the BI of the tourist.

H.2: FR affects the BI of the tourist.

H.3: TR affects the BI of the tourist.

H.4: SPR affects the BI of the tourist.

H.5: PR affects the BI of the tourist.

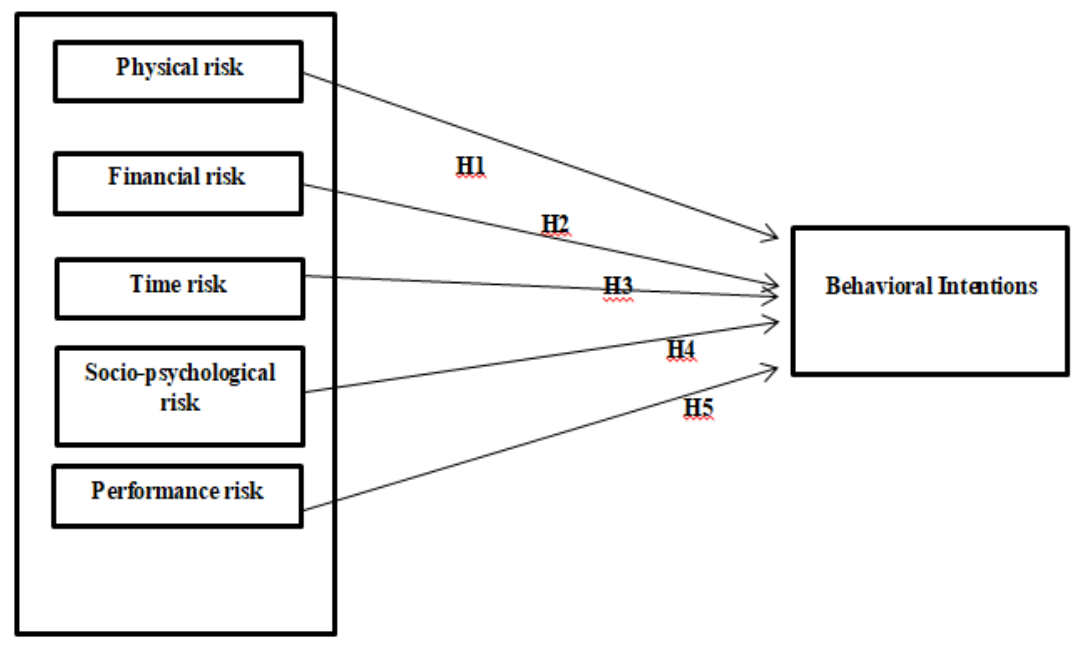

Figure 1. Conceptual model of the relationship between study variables

\section{METHODOLOGY}

\section{Data collection}

The current research aimed to investigate the effect of perceived risks on European tourist BI directly after their visit to Jordan in 2018 (June 2018-August 2018). The study used a purposive sampling method since it is not possible to determine the exact population size. Trained assistances have approached the European tourists while they are waiting to leave Jordan via its major Queen Alia International Airport (QAIA) based on face-to-face. As suggested by Mill and Morisson, (2002), the trained assistances targeting the respondents who meet the following inclusion criteria: (1) European tourists, (2) visiting Jordan for tourism activities, (3) over 18 years. A self-administered survey was conducted as a technique for data collection. A total of 400 questionnaires were distributed among European tourists. Out of which, 339 were usable for analysis taking into consideration the incomplete, erroneous and not returned survey, resulting in an $85 \%$ response rate.

\section{Study Instrument}

Originally, the study scale contained 35 items. Though, the questionnaire statements were updated to suit the context of this study based on advice and input from tourism experts and four academics at Irbid National University. Furthermore, before the study was conducted, a pilot test was carried out on 20 postgraduate students in tourism management to determine how well each scale captured the construct it was supposed to measure. As indicated by Hair et al. (2006), items that loaded less than 0.40 should be removed. As revealed in the Table (1) below, the results of the reliability tests for each variable showed that the alpha of Cronbach was above .70, which is considered adequate for exploratory studies.

Table 1. Result of reliability analysis (Data Source: Data Processing Results, 2019)

\begin{tabular}{|c|c|}
\hline Study factors & Cronbach, $\alpha$ \\
\hline The Scale of Perceived Risks & .90 \\
\hline PHR & .82 \\
\hline FR & .85 \\
\hline PR & .84 \\
\hline TR & .78 \\
\hline SPR & .79 \\
\hline BI & .86 \\
\hline
\end{tabular}

The questionnaire was ready in four languages as the research sample was the European tourists; these are the original Englis copy, German, French, and Russian translated by professional translators and retranslated back to English to ensure accuracy of meaning. The final version of the questionnaire consisted of 25 items in three sections. The first part shows the socio-demographic variables of the respondents, such as nationality, age, gender, income and education through a categorical scale. Following the previous literature review, the second part of the questionnaire consisted of 20 items related to perceived risks derived from five risk dimensions adopt ed from the research Fuchs and Reichel (2006) which adopted and evaluated it from the previous work of Roehl and Fesenmaier (1992). These five 
dimensions are PHR, FR, TR, SPR, and PR. The third part of the questionnaire included 5 items on the BI of the tou rists adopted from Pike et al. (2010) and Huang and Hsu (2003). The scales for the perceived risk dimensions and tourist BI were measured by means of a five point-Likert scale with anchors ranging from (1) strongly disagree to (5) strongly agree.

\section{FINDINGS}

\section{Demographic profile of the respondents}

The demographic profile of the respondents shows that $19 \%$ of those surveyed were from Russia and Ukraine, $18.5 \%$ were UK and Netherlands residents, 10\% from Germany, 7.4\% from Switzerland, 7.4\% resided in France, 5.9\% resided in Sweden, 5\% from Portugal, and the remaining $28.5 \%$ from other European countries. Of those surveyed, $57.2 \%$ were women and 48.2 men. The majority of the visitors were between 26 to 40 years of age (approximately 45\%). About $44 \%$ of the surveyed have a bachelor's degree and 34\% had a master degree. In terms of monthly family income, $46.1 \%$ of the respondents failed in the category of $1500-3000$ Euros per month. Finally, about $70 \%$ of the respondents using the group packed tour as their travel arrangement method.

\section{Descriptive statistics}

Regarding the sample's average value for the PHR perceived in Jordan, European visitors have a low average value for the PHR perceived during their visit to Jordan (the general arithmetic average was 2.4). They are agreed that there are not infectious diseases (H1N1 Influenza, HIV, etc.) in Jordan. Nevertheless, they believed that Jordanians do not receive their behaviour very well including the way they customarily dress and some of their behaviours are not accepted by the local people. In terms of the attitudes of the sample towards the FR they perceived in Jordan; the general arithmetic mean was very high and reached (4.4). European visitors strongly believe that Jordan's holiday is more costly than any other vacation, and they don't think they've got enough service for the amount they paid (money value). Regarding the PRin Jordan, the general arithmetic mean was low reaching (2.4). European visitors strongly believe that Jordanians are very friendly, and the food is very good. Though, accommodations in Jordan are still considered unsatisfactory in terms of quality of service.

The general arithmetic mean of the SPR perceived by European tourists was low reaching (2.1). European tourists see Jordan as a good destination tailored to their lifestyle and their family. However, they were agreed that their family and friends were shocked by their decision to travel to Jordan. Lastly, the general arithmetic mean of TR in Jordan was relatively low (2.7). They agreed that their holiday in Jordan is not a waste of time. It could be inferred that European visitors do not accept that their vacation in Jordan was a waste of their precious holiday.With regard to the intention of the European tourists to visit Jordan in the future and their willingness to separate WOM (Tourist BI), the general arithmetic means were high (4.0). This high mean value indicates that respondents plan to return to Jordan in the future and/or promote and recommend Jordan to others as a TD. They are strongly agreed that they will encourage friends and relatives to visit Jordan.

\section{Correlation analysis}

Correlation analysis was conducted on the data of the survey in order to obtain an understanding of the association between the study variables based on the independent variable of the five perceived risk dimensions (PHR, FR, TR, SPR, and PR) against the tourist's BI as the dependent variable.

Table 2. Correlations of the study variables (Data Source: Data Processing Results, 2019)

\begin{tabular}{|c|c|c|c|c|c|c|c|}
\hline & Variables & $\mathbf{1}$ & $\mathbf{2}$ & $\mathbf{3}$ & $\mathbf{4}$ & $\mathbf{5}$ & $\mathbf{6}$ \\
\hline 1 & BI & 1 & & & & & \\
\hline 2 & PHR & $-.601^{* *}$ & 1 & & & \\
\hline 3 & FR & $-.671^{* *}$ & $.234^{* *}$ & 1 & & \\
\hline 4 & TR & $-.592^{* *}$ & $.333^{* *}$ & $.454^{* *}$ & 1 & & \\
\hline 5 & SPR & $-.115^{* *}$ & $.627^{* *}$ & $.513^{* *}$ & $.545^{* *}$ & 1 & \\
\hline 6 & PR & $-.132^{* *}$ & $.445^{* *}$ & $.644^{* *}$ & $.344^{* *}$ & $.578^{* *}$ & 1 \\
\hline
\end{tabular}

The above table shows that all perceived risk dimensions in the research model are negatively and substantially associated with BI, which means that as risk dimensions decrease, the BI of the visitor to revisit and recommend Jordan to others as a TD should increase. In addition, all five perceived risk dimensions are positively correlated. All the correlation values were below 0.68 and in the expected direction. More specifically, there was a strong correlation between FR and the BI of tourists $(r=.671)$, followed by clear associations between PHR and TR with tourist BI $(r=.601)$ and $(r=.592)$ correlations respectively. However, there was a low correlation between PR and SPR with the BI of the tourist with the correlation between $(\mathrm{r}=.132)$ and $(\mathrm{r}=.115)$ respectively.

\section{Hypotheses testing}

The study used multiple regressions to test the study's hypotheses as more than one independent variable influences the dependent variable. Because regression analysis is very sensitive to outliers, standardized residual values above 3.0 or below 3.0 have been removed in the regression analysis in the SPSS package by case diagnosis. To check the hypotheses H.1, H.2, H.3, H.4, and H.5, multiple regression analysis was carried out between the perceived risk dimensions of the destination as independent variables and the BI of the tourists as the dependent variable. From the first run of the test, the casewise analysis reveals that observation numbers 70,55 , and 219 were considered to be outliers and therefore removed in the next run of regression. The calculated $\mathrm{F}$ value at the confidence level $(\alpha \leq$ $0.05)$ is higher than the tabulated $\mathrm{F}$ value, and the statistical significance level value is lower than the confidence level value $(\alpha \leq 0.05)$. The F-statistic $(\mathrm{F}=16,556 \mathrm{p}<0,001)$ shows a significant relationship between independent and dependent variables.

The $\mathrm{R}$ square obtained for the five perceived risk dimensions rating means that the perceived risk dimensions of the tourists can explain about the 24 percent in the BI of the tourists $\left(\mathrm{R}^{2}=0.237\right)$. In other words, $24 \%$ of the shift in the degree of tourist $\mathrm{BI}$ can be explained by the five perceived risk dimensions included in the regression equation. The result from the multiple regression analysis exposed two of the dimensions included in the equation of regression that emerged as important predictors. In particular, FR(r=0.194) and $\mathrm{PR}(\mathrm{r}=0.217, \mathrm{p}<0.001)$ found to had significant relationships with tourist BI. It is fair to conclude in this case that $\mathrm{H} 2$ and $\mathrm{H} 5$ hypotheses have been supported. Contrary to the hypotheses, the result showed that PHR $(\beta=0.071)$, TR $(\beta=0.088)$ and SPR $(\beta=0.069)$ were not important in tourist BI ( $p>0.001)$. Therefore, $\mathrm{H} 1, \mathrm{H} 3$, and $\mathrm{H} 4$ hypotheses have not been accepted. Based on the size of beta values, the most influential variables of the predictor on tourist BI were PR $(\beta=0.023)$, followed by FR $(\beta=0.019)$. It is important to note that the tolerance and VIF values shown in the output suggest that among the independent variables there is no multicollinearity effect on dependent variables. 


\section{DISCUSSIONS OF RESULTS}

Since Jordan is situated between Palestine, Israel, Egypt, Iraq, and Syria, in the last two decades Jordan's reputation as a tourist destination has been negatively affected (Liu et al., 2016). This study provided empirical evidence of the effects of perceived risks of Jordan as TD on the BI of European tourists. The findings showed that both FR and PR had a significant impact on the BI of the visitors. The current findings of the study were in line with Al Muala's findings (2010); and Schneider and Sonmez (1999), who previously studied Jordan's destination image as a destination for tourism. It was not surprising that PHR associated with Jordan as TD had no effect on the BI of the tourists. The tourists experienced a safe and secure TD after their visit to Jordan, so PHR did not seem to be important to the tourists who were there as a study by Fuchs and Reichel (2011); and a study by Harahsheh (2010) found it. With a mean reached (4.4), this study showed that European tourists considered Jordan as an expensive destination for tourism where they did not get value for their money. In addition, they strongly believe that a holiday in Jordan is more costly than any other vacation (mean 4.5). That is because Jordan is a poor country where the government's main income comes from taxes on services and products, particularly tourism. The Economist Intelligence Unit, for example, ranked Amman as the Arab world's most expensive city in 2015 (Jordan Times, 2015). One of the current study concerns was the PHR of European visitors in Jordan. Generally speaking, European visitors have a medium to a low value in terms of PHR during their visit to Jordan (the general arithmetic mean was 2.4). They also accepted, however, that the local people do not support some of their behaviours. This may be because Jordan is a Muslim country whereas most European tourists are Christians with different religions and cultures. Most respondents agreed that Jordan should be visited and recommended as a safe and secure destination for tourism, so there is no concern about snatching, terrorism, and infectious diseases. The result of the study confirmed that FR associated with Jordan as a destination for tourism had a negative and significant impact on the BI of European tourists. That is, the less FR they perceive, the more likely they are to revisit the destination and recommend it. Regarding the PR, the European tourists found local people in Jordan offering a friendly environment. Though, they still believe that accommodation in Jordan is not adequate in terms of quality of service. Furthermore, they have debated several problems such as public transport and cleanliness that the industry needs to improve quickly. This could be linked to the value of money mentioned earlier, where visitors pay a good amount of money in five-star hotels or resort hotels and expected very high service quality. Giving the fact that European tourists are known as a highly sensitive segment market to the service quality and the variety of options available, so lack of food and accommodation options at multiple prices will discourage them from visiting Jordan. Finally, the results suggested that the three dimensions of risk (PHR, TR, and SPR) did not have any significant effect on the BI of European visitors.

\section{CONCLUSION}

As indicated in the literature, tourists are concerned about the quality of the services they will receive during their visit (PR), hence, tourism service providers in Jordan should double their efforts to provide tourist experiences of high quality to ensure that visitors gain valuable experiences during their stay. In addition, there should be a range of hotels and places to eat at the destination, not just a five-star service viewed by European visitors as costly and not a value for money. It is very difficult to sell Jordan if many European visitors and tour operators see it as a pricy destination. It is therefore recommended that the Jordanian government reduces taxes that impose on tourism facilities such as hotels, transportation, food and beverages, and entrance fees at TD attractions in order to make Jordan more competitive in price than those that have the opposite effect.Few studies -to the best of the researcher's knowledge- have examined the relationship between perceived risk dimensions and BI, especially in the case of European travellers to Jordan. A number of contributions were made from this study. First, the outcomes of evaluating the relationship between these variables will help a destination with potential marketing campaigns aimed at increasing market share by changing negative perceptions and reinforcing positive perceptions. Secondly, some researchers have criticized the exciting theories because they do not take into account variables such as perceived risks in the selection process for TD. Roehl and Fesenmaier (1992), who pioneered tourist perception of risk, found that perceptions of risk and travel behaviour seem specific to the situation, suggesting that travelers perceive risks differently to different destinations and therefore need to study destination-specific perceptions of risk. For instance, a study by Chew and Jahari (2014) addressed the risk of radiation and its effect on Japan as an image of a TD, which cannot be extended to Jordan as a TD. Consequently, a study that sheds light on risk-related perceptions among potential European tourists was significant.

Thirdly, it is very important to study the BI of visitors, whether by their desire to return or their willingness to recommend the destination and distinguish positive feedback, as it can help to predict whether the target customers will become long-term customers and bring more income to businesses by creating an appealing picture of the destination and increasing their marketing efforts to optimize them. Lastly, the population of this study was the European tourists who visited Jordan and are ready to return to their countries, so this study inspects tourists' perceptions of specific and actual risks rather than general evaluations that find it an important strategy for developing and recovering the image of the TD. As a final point, this study had some limitations could be considered for further research. The results of this study were based on a sample of European tourists. Future research may concentrate on different segment markets, such as tourists from Asia and the Middle East. In addition, future research could be carried out not only on the leaving visitor, but also in two lags of time (by their arrivals and their departure). Second, data from the study were collected in the summer while different studies collected data in different seasons (e.g. winter) which could lead to better result. Finally, future study may divide repeated visitors from first-time visitors as the visitors ' perceptions of the destination may vary within the two groups.

\section{REFERENCES}

Ahmed, T., \& Abdul-Kadir, A. (2013). Impact of information sources on the decision makes process of travel to the Egyptian tourist destination after January 25, 2011. Tourism: Tourism: An International Interdisciplinary Journal, 61(4), 395-423. https://hrcak.srce.hr/113261

Al Muala, A. (2010). Antecedent and Mediator of Actual visit behavior amongst international tourists in Jordan. Doctor of philosophy University Utara Malaysia November. http://etd.uum.edu.my./2725/

Al-Oun, S., \& Al-Homoud, M. (2008). The potential for developing community-based tourism among the Bedouins in the Badia of Jordan. Journal of Heritage Tourism, 3(1), 36-54. https://doi.org/10.1080/1743873x.2008.9701249

Artuğer, S. (2015). The effect of risk perceptions on tourists' revisit intentions. European Journal of Business and Management, 7(2), 36-43.

Bao, T., \& Chang, T.L.S. (2014). Finding disseminators via electronic word of mouth message for effective marketing communications. Decision Support Systems, 67(1), 21-29. https://doi.org/10.1016/j.dss.2014.07.006

Barlas, A., Mantis, K., \& Koustelios, A. (2010). Achieving positive word-of-mouth communication: the role of perceived service quality in the context of Greek ski centres. World Leisure Journal, 52(4), 90-297. https://doi.org/10.1080/04419057.2010.9674654

Blackwell, R.D., Miniard, P.W., \& Engel, J.F. (2001). Consumer Behavior, Fort Worth, Harcourt College.

Castro, C.B., Armario, E.M., \& Ruiz, D.M. (2007). The influence of market heterogeneity on the relationship between a destination's image and tourists' future behavior. Tourism Management, 28(1), 175-187. https://doi.org/10.1016/j.tourman.2005.11.013

Chew, T.Y.E., \& Jahari, A.S. (2014). Destination image as a mediator between perceived risks and revisit intention: A case of post-disaster Japan. Tourism Management, 40(1), 382-393. https://doi.org/10.1016/j.tourman.2013.07.008 
Confente, I., \& Russo, I. (2015). Why do People Talk? A Comparison Between Offline WOM and Online WOM. In ECSM2015-Proceedings of the 2nd European Conference on Social Media 2015: ECSM 2015, Academic Conferences Limited.

Cui, F., Liu, Y., Chang, Y., Duan, J., \& Li, J. (2016). An overview of tourism risk perception. Natural Hazards, 82(1), 643-658. https://doi.org/10.1007/s11069-016-2208-1

El-Said, O., \& Aziz, H. (2019). Egypt's Competitiveness: Empirical Examination of the Relationship Between Destination Attributes, Tourist Satisfaction, and Behavioral Intentions Among the Hotel Guests. Tourism and Hospitality Management, 25(1), 53-73.

Farajat, S.A., Liu, B., \& Pennington-Gray, L. (2017). Addressing travel writers ${ }^{\text {ee }}$ role as risk brokers: the case of Jordan. Journal of Policy Research in Tourism, Leisure and Events, 9(1), 23-39. https://doi.org/10.1080/19407963.2016.1231194

Fishbein, M., \& Ajzen, I. (1975). Beliefs, Attitude, and intention behavior : An introduction to theory and research. London: Addison-Wesley Publishing Company. https://scinapse.io/papers/2036389121

Fuchs, G. (2013). Low versus High Sensation-Seeking Tourists: A Study of Backpackers' Experience Risk Perception. International Journal of Tourism Research, 15(1), 81-92. https://doi.org/10.1002/jtr.878

Fuchs, G., \& Reichel, A. (2006). Tourist Destination Risk Perception: The Case of Israel. Journal of Hospitality and Leisure Marketing, 14(2), 83-108. https://doi.org/10.1300/j150v14n02_06

Fuchs, G., \& A. Reichel. (2011). An Exploratory Inquiry into Destination Risk Perceptions and Risk Reduction Strategies of First Time vs. Repeat Visitors to a Highly Volatile Destination. Tourism Management, 32(2), 266-76. https://doi.org/10.1016/j.tourman.2010.01.012

Hair, J.F., Black, W.C., Babin, B.J., Anderson, R.E., \& Tatham, R.L. (2006). Multivariate Data Analysis (6 ed.): Prentice Hall.

Harahsheh, S.S. (2010). An evaluation of the image of the Hashemite Kingdom of Jordan in the British and Swedish markets and the implications for marketing the country as a tourism destination. Unpublished PhD Thesis, Bournemouth University.

Hasan, M.K., Ismail, A.R., \& Islam. F. (2017). Tourist risk perceptions and revisit intention: A critical review of literature. Cogent Business and Management , 4(1), 1412874. https://www.tandfonline.com/doi/full/10.1080/23311975.2017.1412874

Huang, S.S., \& Hus, W.K. (2003). Determinants of User Intention toward IT Instruction: an Examination of Internal and External Factors. Knowledge Management and E-Learning: An International Journal, 1(3). https://doi.org/10.34105/j.kmel.2009.01.015

Kozak, M., Crotts, J., \& Law, R. (2007). The impact of the perception of risk on international travellers. International Journal of Tourism Research, 9(1), 233-242. https://doi.org/10.1002/jtr.607

Lehto, X., Douglas, A., \& Park, J. (2008). Mediating the effects of natural disasters on travel intention. Journal of Travel and Tourism Marketing, 23(4), 2943. https://doi.org/10.1300/j073v23n02_03

Litvin, S.W., Blose, J.E., \& Laird, S.T. (2005). Tourists' use of restaurant webpages: Is the internet a critical marketing tool?. Journal of Vacation Marketing, 11(2), 155-161. https://doi.org/10.1177/1356766705052572

Litvin, S.W., Goldsmith, R.E., \& Pan, B. (2008). Electronic word-of mouth in hospitality and tourism management. Tourism Management, 29(3), 458-468. https://doi.org/10.1016/j.tourman.2007.05.011

Liu, B., Schroeder, A., Pennington-Gray, L. \& Farajat, S.A. (2016). Source market perceptions: How risky is Jordan to travel to?. Journal of Destination Marketing and Management, 5(4), 294-304. https://doi.org/10.1016/j.jdmm.2016.08.005

Lončarić, D., Prodan, M., \& Ribarić, I. (2016). The influence of a visitor's perceptions of a museum's website design on behavioural intentios. Ekonomski Vjesnik/ Econoview, 14(1), 65-79. https://hrcak.srce.hr/ojs/index.php/ekonomski-vjesnik/article/view/3969

Madden, K., Rashid, B., \& Zainol. N.A. (2016). Beyond the motivation theory of destination. Tourism and Hospitality Management, 22(2), 247-264. https://doi.org/10.20867/thm.22.2.1

Mill, R.C., \& Morrison, A.M. (2002). The tourism system: An introductory text (4th ed.). Dubuque, IA: Kemdall/Hunt.

Mitchell, V., Davies, D., Moutinho, L., \& Vassos, V. (1999). Using Neural Networks to Understand Service Risk in the Holiday Product, Journal of Business Research. 46(2), 167-180. https://doi.org/10.1016/s0148-2963(98)00020-4

Moisescu, O.I., \& Bertrea, P. (2013). The Impact of Brand Awareness, Brand Knowledge and Price Positioning on Perceived Risks Associated to Buying Online from Travel Agencies. Romanian Journal of Marketing, 8(3), 13-22.

Moutinho, L. (1987). Consumer Behavior in Tourism. European Journal of Marketing. 21(10), 3-44.

Perpiña, L., Prats. L., \& Camprubí, R. (2017). Investigating Perceived Risks In International Travel. Tourismos: An International Multidisciplinary Refereed Journal of Tourism, 12(2).

Phillips, W.J., Wolfe, K., Hodur, N., \& Leistritz, F.L. (2013). Tourist word of mouth and revisit intentions to rural tourism destinations: A case of North Dakota, USA. International journal of tourism research, 15(1), 93-104. https://doi.org/10.1002/jtr.879

Pike, S., Bianchi, C., Keer, G., \& Patti, C. (2010). Consumer-based brand equity for Australia as a long-haul tourism destination in an emerging market. International Marketing Review, 27(4), 434-449. https://doi.org/10.1108/02651331011058590

Rimal, R.N., \& Real, K. (2003). Understanding the influence of perceived norms on behaviors. Communication Theory, 13(2), 184-203. https://doi.org/10.1111/j.1468-2885.2003.tb00288.x

Rittichainuwat, B.N., \& Chakraborty, G. (2009). Perceived travel risks regarding terrorism and disease: The case of Thailand. Tourism Management, 30(3),410-418. https://doi.org/10.1016/j.tourman.2008.08.001

Roehl, W.S., \& Fesenmaier, D.R. (1992). Risk perceptions and pleasure travel: an exploratory analysis. Journal of Travel Research, 30(4), 17-26. https://doi.org/10.1177/004728759203000403

Schneider, I., \& Sonmez, S. (1999). Exploring the tourist image of Jordan. Tourism Management, 20(1), 539-542. https://doi.org/10.1016/s0261-5177(99)00023-0

Sohn, H.K., Lee, T.J., \& Yoon, Y. (2016). Relationship between perceived risk, evaluation, satisfaction, and behavioral intention: A case of local-festival visitors. Journal of Travel \& Tourism Marketing, 33(1), 28-45.

Sönmez, S., \& Graefe, A.F. (1998a). Influence of Terrorism Risk on Foreign Tourism Decisions. Annals of Tourism Research, 25(10), 112-144. https://doi.org/10.1016/s0160-7383(97)00072-

Sönmez, S., \& Graefe, A.F. (1998b). Detraining future behavior from past travel experience and perception of risk and safety. Journal of travel research, 37(1), 171-177. https://doi.org/10.1177/004728759803700209

Stone, R.N., \& Grønhaug, K. (1993). Perceived risk: further considerations for the marketing discipline. European Journal of Marketing, 27(3), 39-50. https://doi.org/10.1108/03090569310026637

Tasci, A.D., Gartner, W.C., \& Cavusgil, S.T. (2007). Conceptualization and Operationalization of destination image. Journal of Hospitality and Tourism Research, 31(2), 194-223. https://doi.org/10.1177/1096348006297290

Thiumsak, T., \& Ruangkanjanases, A. (2016). Factors influencing international visitors to revisit Bangkok, Thailand. Journal of Economics, Business and Management. 4(3), 220-230. https://doi.org/10.7763/joebm.2016.v4.94

Tsaur, S., Tzeng, G., \& Wang, K. (1997). Evaluating tourist risks from fussy perspectives. Annals of Tourism Research, 24(4), 796-812.

Zeithaml, V.A., \& Bitner, M.J. (1996). Services marketing. New York: McGraw-Hill.

Zeithaml, V.A. (1988). Consumer perceptions of price, quality and value: A means-end model and synthesis of evidence. Journal of Marketing, 52(7), 2-22. https://doi.org/10.1177/002224298805200302

*** Country Brand Index, (2018). New York: Future Brand. https://www.futurebrand.com/futurebrand-country-index.

*** Jordan Times. (2015). Jordan's tourism industry feels impact of regional volatility. Retrieved from http://www.jordantimes.com/news/business/jordan\% E2\%80\%99s-tourism-industry-feels-impact-regional-volatility.

*** Jordanian ministry of tourism and antiques. (2018). Tourists arrivals reports. https://www.mota.gov.jo/Contents/statistics_2018Ar.aspx 